Debreceni Egyetem Általános Orvostudományi Kar, Anyagcsere Betegségek Tanszék, Belgyógyászati Intézet, Debrecen, Szegedi Tudományegyetem Általános Orvostudományi Kar, II. Belgyógyászati Klinika és Kardiológiai Központ, Szeged, ${ }^{2}$ Pécsi Tudományegyetem Általános Orvostudományi Kar, Szívgyógyászati Klinika, Pécs, ${ }^{3}$ Debreceni Egyetem Általános Orvostudományi Kar, Gyógyszerfejlesztési Koordinációs Központ, Debrecen, ${ }^{4}$ Semmelweis Egyetem Ấltalános Orvostudományi Kar, I. Belgyógyászati Klinika, Budapest ${ }^{5}$

\title{
A dyslipidaemia szerepe a kardiális autonóm neuropathia kialakulásában 2-es típusú diabeteses betegekben
}

\author{
Sztanek Ferenc dr., Jakab Áron András, ${ }^{(1)}$ Jebelovszki Éva dr., ${ }^{(2)}$ Gaszner Balázs dr., ${ }^{(3)}$ \\ Páll Dénes dr., ${ }^{(4)}$ Kempler Péter dr., ${ }^{(5)}$ Harangi Mariann dr. ${ }^{(1)}$
}

\section{Osszefoglalás}

A2-es típusú diabetes mellitushoz számos mikrovaszkuláris szövödmény, többek között distalis perifériás polyneuropathia és kardiális autonóm neuropathia (CAN) társulhat, amelyek mindegyike hozzájárul a diabeteshez társuló kedvezötlen morbiditási és mortalitási statisztikákhoz. Számos, nagy betegszámon elvégzett klinikai vizsgálat igazolta, hogy a T2DM-hez társuló dyslipidaemia hozzájárul a neuropathia kialakulásához és progressziójához a vércukorkontrolltól függetlenül. Az atherogen dyslipidaemiát az emelkedett szérumtrigliceridszint, a nagy sürüségü lipoprotein koleszterin alacsony szintje és a kicsi, denz alacsony sürüségü lipoproteinrészecskék gyakoribb elöfordulása jellemzi. Számos korábbi vizsgálat eredménye igazolta, hogy a hypertriglyceridaemia és az egyéb lipideltérések szignifikáns és független elörejelzöi a CAN megjelenésének, és a CAN prevalenciája gyakoribb magasabb lipidprofil-kockázati értékek esetén. Ezek az adatok arra utalnak, hogy a lipidszintek jelentös hatást gyakorolnak a CAN kialakulására, ami segithet megérteni biológiai szerepüket is.

Kulcsszavak: 2-es típusú diabetes mellitus, kardiális autonóm neuropathia, dyslipidaemia, hypertiglyceridaemia, nagy sürüségü lipoproteinfrakció

\section{Role of dyslipidemia in the development of cardiac autonomic neuropathy in patients with type 2 diabetes mellitus}

Summary: Type 2 diabetes mellitus is associated with multiple microvascular complications including distal peripheral polyneuropathy and cardiac autonomic neuropathy, all of which contribute to diabetes-associated morbidity and mortality. Several large-scale clinical studies have indicated that dyslipidemia linked to T2DM is associated with the development and progression of neuropathy, independently of glycemic control. Atherogenic dyslipidemia in diabetes is characterized by elevated serum triglyceride and low serum high-density lipoprotein levels, as well as by high prevalence of small dense low-density lipoprotein particles. The findings of several previous studies offer evidence that hypertriglyceridemia and the further abnormalities of lipid profile are significantly and independently associated with CAN, and that CAN prevalence was frequent among patients with higher lipids profiles risk scores. These findings indicate that the lipids profile might influence the development of CAN, providing insight into biological functions.

Keywords: type 2 diabetes mellitus, cardiac autonomic neuropathy, dyslipidemia, hypertriglyceridemia, highdensity lipoprotein 
Rövidítésjegyzék:

Apo B100: apolipoprotein B100; CETP: koleszterinészter-transzfer fehérje (cholesteryl ester transfer protein); DAN: diabeteses autonóm neuropathia; DSPN: distalis sensoros polyneuropathia; FFA: szabad zsírsav (free fatty acid); HDL: nagy sűrüségú lipoprotein (high-density lipoprotein); HSL: hormonszenzitív lipáz (hormone-sensitive lipase); HTGL: hepatikus triglicerid-lipáz; IDL: közepes sürüségü lipoprotein (intermediate-density lipoprotein); IRS: inzulinreceptor-szubsztrát (insulin receptor substrate); LOX-1: lecitin-szerű oxLDL receptor (lecitin-like oxLDL receptor); LPL: lipoprotein-lipáz; MTP: mikroszomális transzfer fehérje (microsomal transfer protein); NRF-1: nukleáris respiratorikus faktor-1; PGC-1 a: peroxisoma-proliferátor-aktivált gammareceptor-koaktivátor-1-alfa (peroxisome proliferator-activated receptor gamma coactivator 1-alpha); PKC: proteinkináz-C; ROS: reaktív oxigéngyökök (reactive oxygen species); sdLDL: kis, denz alacsony sürüségü lipoprotein (small, dense low-density lipoprotein); TGF- $\beta$ : transzformáló növekedési faktor- $\beta$ (transforming growth factor beta); VLDL: nagyon alacsony sürüségü lipoprotein (very-low-density lipoprotein)

$\mathrm{A}$ 2-es típusú diabetes mellitus előfordulási gyakorisága az elhízás és túlsúly gyakoriságának növekedésével párhuzamosan folyamatosan nő világszerte. 2018-ban a T2DM-ben szenvedő betegek arányát a felnőtt lakosság 8,8\%-ára, számát mintegy 500 millióra becsülték, és a prevalencia a fejlett és fejlődő országokban is emelkedik. ${ }^{1}$ Ezzel egyidejüleg, a diabeteshez társuló szövődmények arányában ugyanilyen drasztikus emelkedés várható. Így egyre nagyobb figyelem irányul a cukorbetegség egyik legritkábban felismert és nehezen kezelhető szövődményére, az autonóm idegrendszer károsodása okozta súlyos kardiovaszkuláris működészavarra, amelyet diabeteses autonóm neuropathiaként (DAN) ismernek. A morbiditás és mortalitás szempontjából kiemelt fontosságú a kardiális autonóm neuropathia (CAN), amely a T2DM-ben 15 éves betegségtartam esetén a betegek akár 65-73\%-ában kimutatható, és szorosan

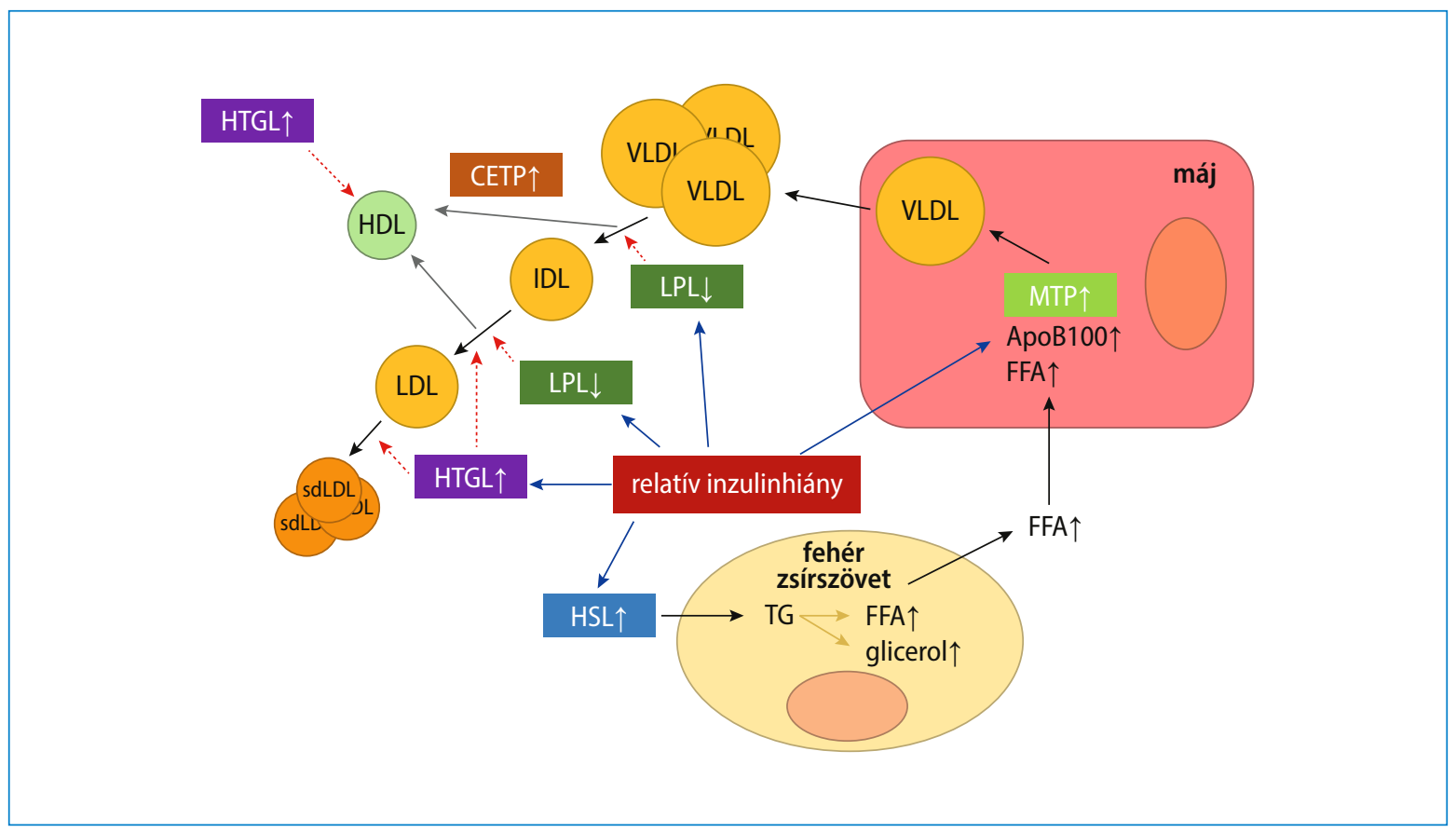

1. ábra. A jellegzetes diabeteses lipideltérések kialakulásának mechanizmusa 
összefügg a szénhidrátháztartás kontrolljával és a hemoglobin $\mathrm{A}_{1 \mathrm{c}}\left(\mathrm{Hb}_{1 \mathrm{c}}\right)$ szintjével. ${ }^{2}$ Egyes vizsgálatok alapján a CAN már prediabetesben is kialakulhat, különösen a csökkent glukóztolerancia és emelkedett éhgyomri vércukorérték együttes előfordulásával járó esetekben, ahol a prevalencia elérheti a $11,4 \%$-ot. ${ }^{3}$ A CAN jelenléte mind 1-es típusú, mind 2-es típusú cukorbetegségben a jövőbeni szív- és érrendszeri betegségek előfordulásának kockázati tényezője, ezért a korai diagnosztikája jelentős szereppel bírhat a fő kardiovaszkuláris események, mint a szívizominfarktus, stroke és szívelégtelenség megelőzése szempontjából. ${ }^{4}$

Ugyancsak gyakori a cukorbetegséghez társuló mennyiségi és minőségi lipideltérések megjelenése, amelyeket összefoglalóan diabeteses, vagy más néven atherogen dyslipidaemiának neveznek. A T2DM-re jellemző lipideltérések közül az emelkedett trigliceridszint, a kicsi, denz alacsony sűrűségű lipoprotein (sdLDL) részecskék magasabb aránya és a nagy sűrűségü lipoprotein (HDL) alacsony szintje a legjellemzőbb. A lipideltérések kialakulásának hátterében a szabad zsírsavak (FFA) szintjének az inzulinrezisztencia miatti emelkedése áll, ami a kilomikron és a verylow-density lipoprotein (VLDL) fokozott termeléséhez vezet mind éhgyomri, mind postprandialis állapotban. ${ }^{5}$

A korszerű vizsgálati módszerekkel a diabeteses dyslipidaemia néhány további komponensét is azonosították, igazolódott például a közepes sűrűségű lipoprotein (IDL) magasabb szintje. Leírták számos enzim expressziójának és szabályozásának a zavarát, köztük a hormonszenzitív lipáz (HSL), a mikroszomális transzfer fehérje (MTP), a lipoproteinlipáz (LPL) és a hepatikus trigliceridlipáz (HTGL) nem megfelelő működését a fokozott inzulinrezisztencia és a relatív inzulinhiány következményeként (1. ábra). ${ }^{6}$

Bár a DAN a cukorbetegség egyik leggyakoribb szövődménye, gyakran későn kerül felismerésre, ami jelentősen hozzájárul a diabeteses betegek életminőségének romlásához és a korai halálozás magas kockázatához. Míg a perifériás neuropathia kialakulásában a dyslipidaemia oki szerepe egyértelműnek tűnik, ${ }^{7} \mathrm{az}$ autonóm neuropathia kialakulásában betöltött szerepéről kevesebb adat áll rendelkezésre.

\section{A dyslipidaemiához társuló neuropathia kialakulásának és progressziójának lehetséges mechanizmusai}

A neuropathia kialakulásának pontos mechanizmusa dyslipidaemiában nem tisztázott, de a lipidabnormalitásokkal járó fokozott oxidatív stressznek lehet a legfontosabb szerepe. A fokozott oxidatív stressz elősegíti a neuropathia kialakulásban kulcsszerepet játszó kóros metabolikus útvonalak, így a poliol- és hexózamin-útvonal, az előrehaladott glikációs végtermékek, a poli-ADPribóz polimeráz és a proteinkináz-C (PKC) aktivációját. ${ }^{8}$ Patkánymodellben önmagában a zsírban gazdag étrend növeli az oxidatív stressz mértékét, és károsítja a sensoros és motoros idegi vezetési sebességet még a csökkent glukóztolerancia kialakulása előtt. ${ }^{9}$

Az LDL oxidatív módosulása és az oxidált LDL kötődése a lecitin-like oxLDL receptorokhoz (LOX-1) a NADPHoxidáz aktivációján keresztül növeli a reaktív oxigéngyökök (ROS) termelését. A dorzális ideggyökök ganglionjai képesek a LOX-1-expresszióra, és distalis polyneuropathiás betegekben a folyamat jelenlétét igazolták. ${ }^{10} \mathrm{Az}$ FFA emelkedett szintje az intracelluláris diacilglicerol- és ceramidszint emelkedésével jár, ami aktiválja a PKC- $\theta$ és - $\delta$ izoformákat és egyes szerin-treonin kinázokat, amelyek az inzulinreceptor-szubsztrát (IRS) foszforilációjához vezetnek csökkentve annak jelátviteli kapacitását. ${ }^{11}$

Az emelkedett FFA-szint tovább növeli a telített zsírsavak magas citoplazmatikus koncentrációját, ami a sejtmembrán szerkezetének megbomlásához vezet, csökkentve annak flexibiltását, elektromos vezetőképességét és jelátviteli hatékonyságát. ${ }^{12}$ A magas zsírtartalmú étrend okozta FFA-emelkedés emellett gátolja a légzési lánc megfelelő működését, ami a zsírsavak tökéletlen oxidációjához vezet. Ezek a peroxisoma-proliferátor-aktivált gammareceptor koaktivátor-1-alfa (PGC-1 $\alpha)$ és a nukleáris respiratorikus faktor-1 (NRF-1) csökkent expresszióját váltják ki, ami a mitokondriális ATPtermelés csökkenését, ezzel a sejtműködés energetikai zavarát okozza a neuronokban. ${ }^{13}$

A szfingolipidek a sejtmembránok felépítésében és a jelátviteli folyamatokban kulcsszerepet játszanak. Egyes, a cukorbetegekben felszaporodó atípusos szfingolipidek, például 


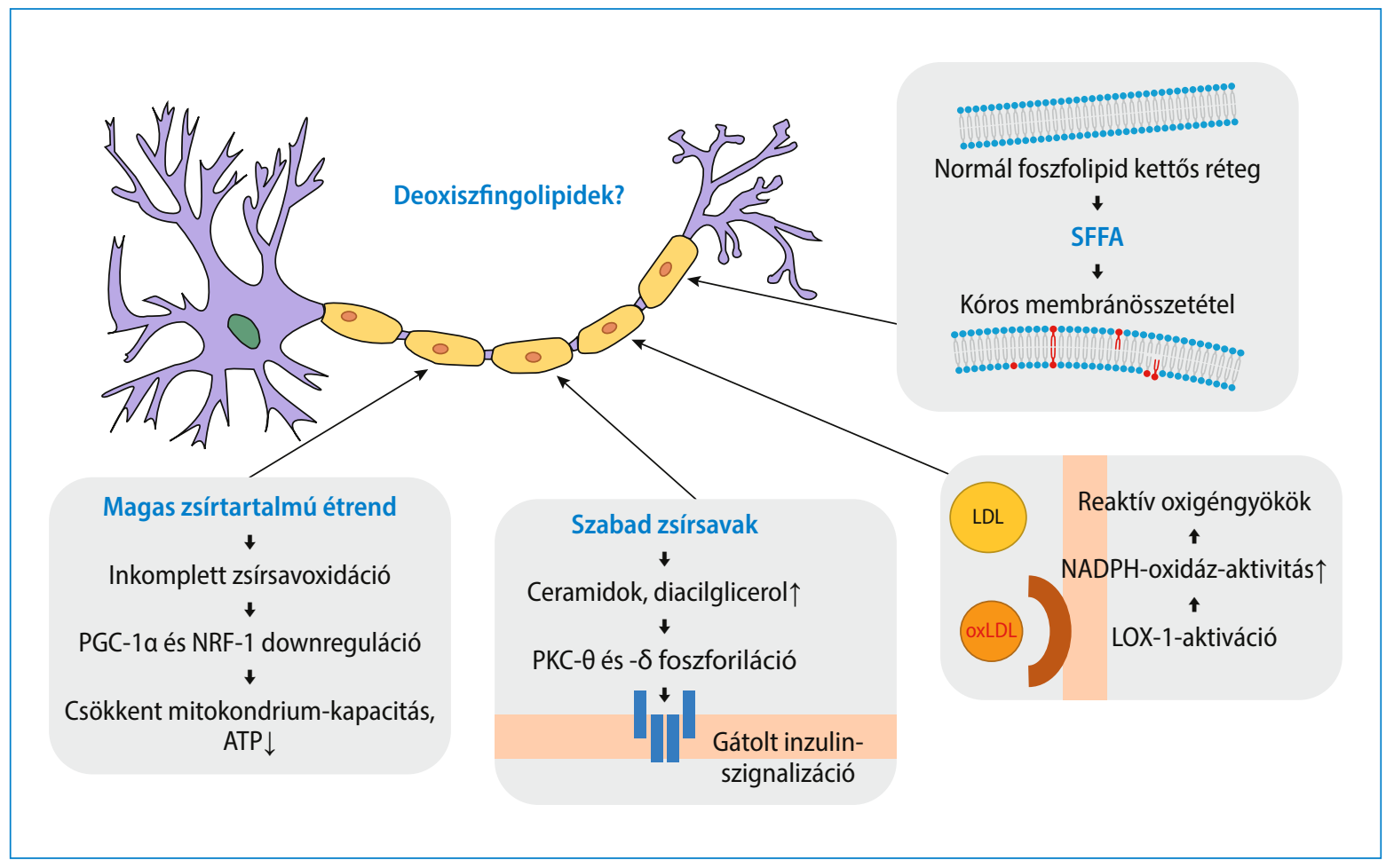

\section{2. ábra. A dyslipidaemiához társuló neuropathia kialakulásának és progressziójának lehetséges mechanizmusai}

a dezoxiszfingolipidek szintén neurotoxikus hatást fejtenek ki, eddig ismeretlen mechanizmuson keresztül. ${ }^{14} \mathrm{Az}$ idegsejtek és rostok károsodásának legfontosabb lehetséges okait a 2. ábra foglalja össze.

A dyslipidaemiához társuló alacsony fokú gyulladás szerepe szintén felvetődött, mivel a gyulladásos citokinek, köztük a tumor nekrózis faktor- $\alpha$ (TNF- $\alpha$ ) és a transzformáló növekedési faktor faktor- $\beta$ (TGF- $\beta$ ) szintje a zsírban gazdag étrend hatására szintén megemelkedik. Igaz, a gyulladást csökkentő gyógyszeres kezelések hatékonyságát a neuropathia progresszióját illetően eddig nem bizonyították. ${ }^{15}$

\section{A magas trigliceridszint következményei}

Amellett, hogy a magas trigliceridszint fokozza a hasnyálmirigy-gyulladás kockázatát, ${ }^{16}$ a hypertriglyceridaemia elősegíti az érelmeszesedés kialakulását. ${ }^{17}$ Emellett hozzájárul a cukorbetegség számos szövődményének, köztük a retinopathia, ${ }^{18}$ a nephropathia ${ }^{19}$ és a neuropathia kialakulásához is. Bár a pontos mechanizmus nem minden részletében ismert, a nem észterifikált zsírsavak emelkedett trigliceridszinthez társuló magas szintje emeli az össz- és mitokondriális szuperoxid-termelést és a $\mathrm{NAD}(\mathrm{P}) \mathrm{H}$-oxidáz aktivitást, vagyis fokozott oxidatív-nitrozatív stressz kialakulásával jár, ami részben direkt módon, részben az endothelfunkció károsításán keresztül a neuropathiás szövődmények kialakulásához vezethet. ${ }^{20}$

Egy korábbi prospektív vizsgálatban 16 súlyos hypertriglyceridaemiás beteg esetén idegi ingervezetés és autonóm funkcionális tesztek alkalmazásával az esetek 37\%-ában találtak tünetmentesen kialakuló motoros, sensoros és autonóm axonális polyneuropathiát. ${ }^{21}$ Egy másik tanulmányban 24 jelentősen emelkedett trigliceridszintű (szérumtriglicerid $>300 \mathrm{mg} / \mathrm{dl}$, azaz 3,4 mmol/l feletti), neuropathiás tünetekkel nem rendelkező betegnél végeztek elektroneurográfiás vizsgálatot. A betegek 70,8\%-ában a nervus suralis distalis sensoros 
latencia szignifikáns meglassulást mutatott. Az esetek 54,2\%-ában észlelték a vezetési sebesség csökkenését a nervus tibialis posterior és 33,3\%-ában a nervus suralis vizsgálatakor. ${ }^{22}$ Mindez arra utal, hogy a hypertriglyceridaemia önmagában is képes fokozni a neuropathia kialakulásának kockázatát, a cukorbetegség jelenlététől függetlenül.

Egy további vizsgálatban 427 enyhe és közepesen súlyos diabeteses neuropathiás betegnél a szérumtriglicerid-szint jól korrelált a nervus suralis mielinizált rostjainak denzitásával, függetlenül a betegség fennállási idejétől, a betegek életkorától, a vércukorkontrolltól és számos egyéb változótól. ${ }^{7}$

$\mathrm{Az}$ Anglo-Danish-Dutch Study of Intensive Treatment in People With Screen-Detected Diabetes in Primary Care (ADDITION-Denmark) vizsgálat holland ágán 777 T2DM-beteg 6 éves és 443 beteg 13 éves követése során kardiális autonóm reflextesztek elvégzésével vizsgálták a CAN jelenlétét és annak kockázati tényezőit. $\mathrm{A} \mathrm{HbA}_{1 c}$, a testsúly, a testtömegindex mellett a trigliceridszint esetén találtak szignifikáns összefüggést a CAN pervalenciájával, bár időben az összefüggések szorossága változott. ${ }^{23}$

Egy másik vizsgálatban 600 diabeteses beteget bevonva azt találták, hogy a T2DM-betegek 44,3\%-ában fordult elő CAN, amelynek egyéb kockázati tényezők mellett a trigliceridszint is független prediktora volt. ${ }^{24}$

A Utah Diabetic Neuropathy Study során 218 neuropathiás szövődménnyel rendelkező és nem rendelkező T2DM-betegnél vizsgálták a kockázati tényezők előfordulását. A vizsgálatok során kérdőívek, Utah Early Neuropathy Scale, idegi vezetési sebesség mérés, a vibráció- és hidegérzetet mérő kvantitatív sensoros tesztek, kvantitatív szudomotoros axon reflex tesztek és bőrbiopsziás mintából végzett intraepidermális idegrostdenzitás-mérés segítségével határozták meg a neuropathia jelenlétét. Legalább 3 eltérés esetén valószínű, 1-2 eltérés esetén lehetséges neuropathiát véleményeztek. A többvariációs analízis során azt találták, hogy az elhízás és az emelkedett trigliceridszint a kis, nem mielinizált axonok számának csökkenésével jár, míg az emelkedett $\mathrm{HbA}_{1 \mathrm{c}}$-szint a nagy mielinizált rostok számának csökkenéséhez vezet, ami arra utalhat, hogy a hypertriglyceridaemia és a hyperglykaemia hatása a neuropathia kialakulására eltérő lehet. ${ }^{25}$
Egy összesen 72267 beteg bevonásával elvégzett tanulmányban a lipidparaméterek és a mikrovaszkuláris szövődmények közötti összefüggéseket elemezték, a bevont betegek 29,01\%-a esetében igazolták CAN előfordulását. Egyértelmű szoros pozitív összefüggést találtak a trigliceridszint és a CAN kialakulási kockázata között, függetlenül az életkortól, iskolázottságtól és az alkalmazott kezeléstől. ${ }^{26}$

\section{A kicsi, denz LDL-részecskék hatása}

Már a 90-es évek elején leírták, hogy az inzulinrezisztencia a kisebb és sűrűbb LDL-részecskék felszaporodásához vezet. ${ }^{27,28}$ A kicsi, nagy denzitású vagy small dense LDL (sdLDL) részecskék az érelmeszesedés szempontjából nagyobb kockázatot jelentenek, mint a nagyobb LDL-részecskék, mivel könnyebben jutnak be a keringésből az érfalba, affinitásuk az LDL-receptorokhoz kisebb, hosszabb a plazmában a féléletidejük és hajlamosak az oxidációra. ${ }^{29,30}$ A kisebb LDL-partikulumok kialakulásával járó $\mathrm{B}$ mintázatú LDL-részecskék esetén a kardiovaszkuláris megbetegedések kialakulásának kockázata 2-3-szor nagyobb. ${ }^{31}$ A B mintázat és a kisebb LDL-részecskeméret pedig jóval gyakoribb diabetes mellitus esetén, és szoros öszszefüggést mutat a hypertriglyceridaemia és az inzulinrezisztencia súlyosságával. ${ }^{29}$ A koleszterinészter-transzfer fehérje (CETP) mediálta trigliceridtranszport felelős a triglicerid lipoproteinekről az LDL-részecskékre történő áthelyezésére, amely így alkalmas szubsztrátot jelent a HTGL számára, és ennek hatására a trigliceridben gazdag LDL lipolízise során koleszterinben szegény sdLDL keletkezik. ${ }^{32}$ A visceralis zsírszövet mennyisége pozitív korrelációt mutat az sdLDL mennyiségével, így a jelentős visceralis elhízás tovább emeli a sdLDL szintjét. ${ }^{33}$ Bár a trigliceridszint és a csökkent LDL-méret szorosan összefügg, önmagában a hypertriglyceridaemia okozta kisebb LDL-méret nem vezet a kardiovaszkuláris kockázat jelentős emelkedéséhez, mivel az LDL-részecskék mérete mellett azok száma is jelentős tényező. ${ }^{34,35}$ A sdLDL-koleszterin meghatározása ugyanakkor jó markere a kardiovaszkuláris kockázatnak. ${ }^{36}$

A sdLDL-koleszterin jelentősége a diabeteses neuropathia, ezen belül az DAN/CAN 
kialakulásában jóval kevésbé vizsgált terület. Korábban 175 , lipidcsökkentő terápiában nem részesülő diabeteses beteg vizsgálata során azt találták, hogy nők esetén a sdLDL-koleszterin szintje és az sdLDL aránya szignifikánsan nagyobb volt a kardiális autonóm neuropathiás betegekben a CAN-ban nem szenvedőköz viszonyítva. Az átlagos LDLrészecskeméret a CAN független kockázati tényezőjének bizonyult. ${ }^{37}$

\section{Az alacsony HDL-szint szerepe}

A HDL-részecske védő hatása az érelmeszesedés kialakulásával szemben évtizedek óta ismert és jól dokumentált. Az antiatherogen hatáshoz a reverz koleszterintranszport ${ }^{38,39}$ mellett a HDL antioxidáns, antiinflammatorikus és antithrombotikus hatásai is hozzájárulnak. ${ }^{40} \mathrm{Az}$ alacsony HDLszint és az emelkedett kardiovaszkuláris kockázat közötti összefüggést több korábbi multicentrikus vizsgálat is igazolta. ${ }^{41,42,43}$ A HDL szerepe a neuropathia kialakulásában sokak által vizsgált, mégis kérdéses. Egy 90 polyneuropathiás és nem polyneuropathiás diabeteses betegeket vizsgáló tanulmányban a monocyta/HDL-C arányt vizsgálva negatív korrelációt igazoltak a nervus tibialis posterior összetett izom akciós potenciálja és a monocyta/HDL-C hányados között. Ez az arány szignifikánsan magasabb volt a diabeteses polyneuropathiás betegekben a nem polyneuropathiás betegekhez és az egészséges kontrollcsoporthoz viszonyítva. ${ }^{44}$ A már említett ADDITION-Denmark vizsgálat 1533 betegadatának feldolgozása alapján az alacsony HDL-C-szint a diabeteses polyneuropathia független prediktora. ${ }^{45} \mathrm{~A}$ HDL-C-szint és a CAN összefüggésére vonatkozóan jóval kevesebb adat áll rendelkezésünkre. Egy kínai vizsgálatban 455 diabeteses beteg bevonásával nem találtak kapcsolatot a HDL-C-szint és a CAN előfordulási kockázata között. ${ }^{46}$

A már korábban említett, 72267 beteg bevonásával elvégzett tanulmány alapján a HDL-Cszint $1 \mathrm{mmol} / \mathrm{l}$-es emelése a mikrovaszkuláris szövődmények előfordulási gyakoriságát $1 \%$-kal csökkenti, és a HDL-C célértékét elérő betegek esetén a mikrovaszkuláris szövődmények kialakulási esélye szignifikánsan alacsonyabb. Ugyanakkor nem találtak szignifikáns összefüggést a
HDL-C-szint és a CAN előfordulási gyakorisága között. A vizsgálat azonban aláhúzza a megfelelő lipidcsökkentő kezelés és a célértékelérés fontosságát diabeteses betegekben a mikrovaszkuláris szövődmények megelőzésében. ${ }^{26}$

\section{A HDL-funkció jelentősége}

A HDL csökkent szintje mellett diabetesben a HDL funkciója is károsodik. Ismert, hogy diabeteses betegekben a HDL-hez asszociált antioxidáns hatású humán paraoxonáz-1 enzim aktivitása csökkent. ${ }^{47,48}$ A paraoxonáz a hidroperoxidok és hidoxilgyökök hidrolízisével csökkenti az oxidációs folyamatokat, például az LDL oxidatív módosulását. Aktivitását a zsírban gazdag étrend is képes csökkenteni. ${ }^{15}$

A HDL felszínén az apolipoprotein A1-gyel és a paraoxonázzal funkcionális egységet képező, prooxidáns enzim, a mieloperoxidáz szintje ezzel szemben emelkedett cukorbetegség esetén és pozitívan korrelál a coronariabetegség kialakulásának kockázatával T2DM-betegekben. ${ }^{49}$ A Cooperative Health Research in the Region of Augsburg (KORA) F4 vizsgálatba 1069 résztvevőt vontak be, akik közül 40,3\% prediabeteses és 20,5\% T2DMbeteg volt, 181 betegben már a vizsgálat kezdetekor distalis sensoros polyneuropathiát (DSPN) igazoltak. A prospektív vizsgálat során azt találták, hogy az emelkedett mieloperoxidáz-szint pozitívan korrelált a DSPN prevalenciájával. ${ }^{50}$

\section{Összefoglalás}

A T2DM-ben kialakuló jellegzetes lipideltérések: a hypertriglyceridaemia, az emelkedett sdLDLkoleszterin- és alacsony HDL-koleszterin-szint, valamint a HDL funkcionális eltérései jelentősen hozzájárulhatnak a neuropathiás szövődmények, ezen belül a CAN kialakulásához és progressziójához. A mennyiségi eltérések mellett jelentőséggel bírnak a lipidpartikulumok minőségi eltérései is, különösen a HDL esetében, ahol a funkció károsodása fontosabb lehet a mennyiségi változásoknál. Mindez felhívja a figyelmet a diabeteses betegek lipidparamétereinek rendszeres ellenőrzésére, a lipideltérések esetén a neuropathiás szövődmények 
szűrésének és a dyslipidaemia hatékony kezelésének jelentőségére.

\section{Köszönetnyilvánítás}

A publikáció elkészítését az EFOP-3.6.2-16-201700009 számú projekt támogatta.

Közlésre érkezett: 2019. május 20.

Közlésre elfogadva: 2019. október 8.

\author{
A levelezésért felelős szerző címe: \\ Dr. Sztanek Ferenc \\ Debreceni Egyetem Általános Orvostudományi Kar, \\ Anyagcsere Betegségek Tanszék, Belgyógyászati \\ Intézet \\ 4032 Debrecen, Nagyerdei krt. 98. \\ E-mail: sztanek@belklinika.com
}

\section{rrodalom}

1. Zheng Y, Ley SH, Hu FB: Global aetiology and epidemiology of type 2 diabetes mellitus and its complications. Nat Rev Endocrinol 2018; 14(2): 88-98. doi:10.1038/nrendo.2017.151

2. Spallone V, Morganti R, D'Amato C, Greco C, Cacciotti L, Marfia GA: Validation of DN4 as a screening tool for neuropathic pain in painful diabetic polyneuropathy. Diabet Med 2012; 29(5): 578-585. doi:10.1111/j.1464-5491.2011.03500.x

3. Kempler P, Váradi A, Tamás G: Autonomic neuropathy in newly diagnosed diabetes mellitus. Diabetes Care 1993; 16(5): 848-849. doi: $10.2337 /$ diacare. 16.5 .848

4. Kempler P, Tesfaye S, Chaturvedi N, Stevens $L K$, Webb DJ, Eaton S, et al: Autonomic neuropathy is associated with increased cardiovascular risk factors: the EURODIAB IDDM Complications Study. Diabet Med 2002; 19(11): 900-909. doi:10.1046/j.1464-5491.2002.00821.x

5. Soran H, Schofield JD, Adam S, Durrington PN: Diabetic dyslipidaemia. Curr Opin Lipidol 2016; 27(4):313-322. doi:10.1097/MOL.0000000000000318

6. Yanai $\mathrm{H}$, Hirowatari $Y$, Ito $\mathrm{K}$, Kurosawa $\mathrm{H}$, Tada N, Yoshida H: Understanding of diabetic dyslipidemia by using the anion-exchange high performance liquid chromatography data. I Clin Med Res 2016; 8(5): 424-426. doi:10.14740/jocmr2533w

7. Wiggin TD, Sullivan KA, Pop-Busui R, Amato A, Sima AA, Feldman EL: Elevated triglycerides correlate with progression of diabetic neuropathy. Diabetes 2009; 58(7): 1634-1640. doi:10.2337/db08-1771

8. Sztanek F, Molnárné Molnár A, Balogh Z: TThe role of oxidative stress in the development of diabetic neuropathy]. Orvosi Hetilap 2016; 157(49): 1939-1946.

9. Vincent AM, Hinder LM, Pop-Busui R, Feldman EL: Hyperlipidemia: a new therapeutic target for diabetic neuropathy. J Peripher Nerv Syst 2009; 14(4): 257-267. do: 10.1111/j.1529-8027.2009.00237.x

10. Vincent AM, Hayes JM, McLean LL, Vivekanandan-Giri A, Pennathur S, Feldman EL: Dyslipidemia-induced neuropathy in mice: the role of oxLDL/ LOX-1. Diabetes 2009; 58(10): 2376-2385. doi:10.2337/db09-0047

11. Dey D, Basu D, Roy SS, Bandyopadhyay A, Bhattacharya S: Involvement of novel PKC isoforms in FFA induced defects in insulin signaling. Mol Cell Endocrinol 2006; 246(1-2): 60-64. doi:10.1016/j.mce.2005.12.014

12. Weijers RN. Membrane flexibility, free fatty acids, and the onset of vascular and neurological lesions in type 2 diabetes. J Diabetes Metab Disord 2015; 15: 13. doi:10.1186/s40200-016-0235-9

13. Patti ME, Butte AJ, Crunkhorn S, Cusi K, Berria R, Kashyap S, et al: Coordinated reduction of genes of oxidative metabolism in humans with insulin resistance and diabetes: Potential role of $\mathrm{PGCl}$ and NRF1. Proc Natl Acad Sci US A 2003; 100(14): 8466-8471. doi:10.1073/pnas.1032913100

14. Kramer R, Bielawski J, Kistner-Griffin E, Othman A, Alecu I, Ernst D, et al.: Neurotoxic 1-deoxysphingolipids and paditaxel-induced peripheral neuropathy. FASEB J 2015; 29(11): 4461-4472. doi:10.1096/f.15-272567

15. Ozay R, Uzar E, Aktas A, Uyar ME, Gürer B, Evliyaoglu 0 , et al.: The role of oxidative stress and inflammatory response in high-fat diet induced peripheral neuropathy. I Chem Neuroanat 2014; 55: 51-57. doi:10.1016/j.jchemneu.2013.12.003

16. Albai 0 , Roman D, Frandes M: Hypertriglyceridemia, an important and independent risk factor for acute pancreatitis in patients with type 2 diabetes mellitus. Ther Clin Risk Manag 2017; 13: 515-522. doi:10.2147/TCRM.S134560

17. Mazzone T, Chait A, Plutzky J: Cardiovascular disease risk in type 2 diabetes mellitus: insights from mechanistic studies. Lancet 2008; 371(9626): 1800-1809. doi:10.1016/50140-6736(08)60768-0

18. Hammer SS, Busik JV: The role of dyslipidemia in diabetic retinopathy. Vision Res 2017; 139: 228-236. doi:10.1016/j.visres.2017.04.010 
19. Penno G, Solini A, Zoppini G, Fondelli C, Trevisan R, Vedovato M, et al.: Hypertriglyceridemia is independently associated with renal, but not retinal complications in subjects with type 2 diabetes: A cross-sectional analysis of the renal insufficiency and cardiovascular events (RIACE) Italian multicenter study. PLoS One 2015; 10(5): e0125512. doi:10.1371/journal.pone.0125512

20. Lupachyk S, Watcho P, Hasanova N, Julius U, Obrosova IG: Triglyceride, nonesterified fatty acids, and prediabetic neuropathy: role for oxidativenitrosative stress. Free Radic Biol Med 2012; 52(8): 1255-1263 doi:10.1016/j.freeradbiomed.2012.01.029

21. Drory VE, Groozman GB, Rubinstein A, Korczyn AD: Hypertriglyceridemia may cause a subclinical peripheral neuropathy. Electromyogr Clin Neurophysiol 1999; 39(1): 39-41.

22. Kassem HS, Azar ST, Zantout MS, Sawaya RA: Hypertriglyceridemia and peripheral neuropathy in neurologically asymptomatic patients. Neuro Endocrinol Lett 2005; 26(6): 775-779.

23. Andersen ST, Witte DR, Fleischer J, Andersen H, Lauritzen T, Jørgensen ME, et al.: Risk factors for the presence and progression of cardiovascular autonomic neuropathy in type 2 diabetes: ADDITION-Denmark. Diabetes Care 2018; 41(12): 2586-2594. doi:10.2337/dc18-1411

24. Voulgari C, Psallas M, Kokkinos A, Argiana V, Katsilambros N, Tentolouris $\mathrm{N}$ : The association between cardiac autonomic neuropathy with metabolic and other factors in subjects with type 1 and type 2 diabetes. J Diabetes Complications 2011; 25(3): 159-167. doi:10.1016/j.jdiacomp.2010.06.001

25. Smith AG, Singleton JR: Obesity and hyperlipidemia are risk factors for early diabetic neuropathy. J Diabetes Complications 2013; 27(5): 436-442. doi:10.1016/j.jdiacomp.2013.04.003

26. Toth PP, Simko RJ, Palli SR, Koselleck D, Quimbo RA, Cziraky MJ: The impact of serum lipids on risk for microangiopathy in patients with type 2 diabetes mellitus. Cardiovasc Diabetol 2012; 11: 109. doi:10.1186/1475-2840-11-109

27. Selby JV, Austin MA, Newman B, Zhang D, Quesenberry CP, Mayer EJ, et al.: $\mathrm{LDL}$ subclass phenotypes and the insulin resistance syndrome in women. Circulation 1993; 88(2): 381-387. doi:10.1161/01.cir.88.2.381

28. Feingold KR, Grunfeld C, Pang M, Doerrler W, Krauss RM: LDL subclass phenotypes and triglyceride metabolism in non-insulin-dependent diabetes. Arterioscler Thromb 1992; 12(12): 1496-1502.

29. Berneis KK, Krauss RM: Metabolic origins and clinical significance of LDL heterogeneity. I Lipid Res 2002; 43(9): 1363-1379. doi:10.1194/jlr.r200004-jlr200

30. Ivanova EA, Myasoedova VA, Melnichenko AA, Grechko AV, Orekhov AN: Small dense low-density lipoprotein as biomarker for atherosclerotic diseases. Oxid Med Cell Longev 2017; 2017: 1273 042. doi:10.1155/2017/1273042

31. Stampfer MJ, Krauss RM, Ma J, Blanche PJ, Holl LG, Sacks FM, et al.: A prospective study of triglyceride level, low-density lipoprotein particle diameter, and risk of myocardial infarction. JAMA 1996; 276(11): 882-888. doi:10.1001/jama.1996.03540110036029

32. Georgieva AM, van Greevenbroek MM, Krauss RM, Brouwers MC, Vermeulen VM, Robertus-Teunissen MG, et al: Subclasses of low-density lipoprotein and very low-density lipoprotein in familial combined hyperlipidemia: relationship to multiple lipoprotein phenotype. Arterioscler Thromb Vasc Biol 2004; 24(4): 744-749. doi:10.1161/01.ATV.0000119681.47218.a4

33. Okazaki M, Usui S, Ishigami M, Sakai N, Nakamura T, Matsuzawa Y, et al: Identification of unique lipoprotein subclasses for visceral obesity by component analysis of cholesterol profile in high-performance liquid chromatography. Arterioscler Thromb Vasc Biol 2005; 25(3): 578-584. doi:10.1161/01.ATV.0000155017.60171.88

34. Hegele RA, Ginsberg HN, Chapman MJ, Nordestgaard BG, Kuivenhoven JA Averna $M$, et al:: The polygenic nature of hypertriglyceridaemia: implications for definition, diagnosis, and management. Lancet Diabetes Endocrinol 2014; 2(8): 655-66. doi:10.1016/S2213-8587(13)70191-8
35. Hirano T, Ito Y, Koba S, Toyoda M, Ikejiri A, Saegusa H, et al: Clinical significance of small dense low-density lipoprotein cholesterol levels determined by the simple precipitation method. Arterioscler Thromb Vasc Biol 2004; 24(3): 558-563. doi:10.1161/01.ATV.0000117179.92263.08

36. Koba S, Yokota Y, Hirano T, Ito Y, Ban Y, Tsunoda F, et al:. Small LDL-cholesterol is superior to LDL-cholesterol for determining severe coronary atherosclerosis. J Atheroscler Thromb 2008; 15(5): 250-260. doi:10.5551/jat.e572

37. Jang EH, Park YM, Hur J, Kim MK, Ko SH, Baek KH, et al.: Higher levels of small dense low-density lipoprotein (LDL) are associated with cardiac autonomic neuropathy in patients with type 2 diabetes. Diabet Med 2013; 30(6): 694-701. doi:10.1111/dme.12176

38. von Eckardstein A, Nofer JR, Assmann G: High density lipoproteins and arteriosclerosis. Role of cholesterol efflux and reverse cholesterol transport. Arterioscler Thromb Vasc Biol 2001; 21(1): 13-27. doi:10.1161/01.atv.21.1.13

39. Toth PP: Reverse cholesterol transport: high-density lipoprotein's magnificent mile. Curr Atheroscler Rep 2003; 5(5): 386-393.

40. Mineo C, Deguchi H, Griffin JH, Shaul PW: Endothelial and antithrombotic actions of HDL. Circ Res 2006; 98(11): 1352-1364. doi:10.1161/01.RES.0000225982.01988.93

41. Wilson PW, Abbott RD, Castelli WP: High density lipoprotein cholesterol and mortality. The Framingham Heart Study. Arteriosclerosis 1988; 8(6): 737-741.

42. Gordon DJ, Probstfield JL, Garrison RJ, Neaton JD, Castelli WP, Knoke JD, et al.: High-density lipoprotein cholesterol and cardiovascular disease. Four prospective American studies. Circulation 1989; 79(1): 8-15. doi:10.1161/01.cir.79.1.8

43. Acharjee S, Boden WE, Hartigan PM, Teo KK, Maron DJ, Sedlis SP, et al.: Low levels of high-density lipoprotein cholesterol and increased risk of cardiovascular events in stable ischemic heart disease patients: A post-hoc analysis from the COURAGE Trial (Clinical Outcomes Utilizing Revascularization and Aggressive Drug Evaluation). J Am Coll Cardiol 2013; 62(20): 1826-1833. doi:10.1016/j.jacc.2013.07.051

44. Vural G, Gümüsyayla Ş: Monocyte-to-high density lipoprotein ratio is associated with a decreased compound muscle action potential amplitude in patients with diabetic axonal polyneuropathy. Medicine (Baltimore) 2018; 97(42): e12857. doi:10.1097/MD.0000000000012857

45. Andersen ST, Witte DR, Dalsgaard EM, Andersen H, Nawroth P, Fleming T, et al.: Risk factors for incident diabetic polyneuropathy in a cohort with screendetected type 2 diabetes followed for 13 Years: ADDITION-Denmark. Diabetes Care 2018; 41(5): 1068-1075. doi:10.2337/dc17-2062

46. Song $L$, Zhou $L$, Tang Z: An association analysis of lipid profile and diabetic cardiovascular autonomic neuropathy in a Chinese sample. Lipids Health Dis 2016; 15: 122. doi:10.1186/s12944-016-0287-3

47. Abbott CA, Mackness MI, Kumar S, Boulton AJ, Durrington PN: Serum paraoxonase activity, concentration, and phenotype distribution in diabetes mellitus and its relationship to serum lipids and lipoproteins. Arterioscler Thromb Vasc Biol 1995; 15(11): 1812-1828. doi:10.1161/01.atv.15.11.1812

48. Kota SK, Meher LK, Jammula S, Krishna SV, Modi KD: Implications of serum paraoxonase activity in obesity, diabetes mellitus, and dyslipidemia. Indian J Endocrinol Metab 2013; 17(3): 402-412. doi:10.4103/2230-8210.111618

49. Song $P, X U$ J, Song $Y$, Jiang S, Yuan H, Zhang X: Association of Plasma myeloperoxidase level with risk of coronary artery disease in patients with type 2 diabetes. Dis Markers 2015; 2015: 761939. doi:10.1155/2015/761939

50. Herder C, Kannenberg JM, Huth C, Carstensen-Kirberg M, Rathmann W, Koenig W, et al.: Myeloperoxidase, superoxide dismutase-3, cardiometabolic risk factors, and distal sensorimotor polyneuropathy: The KORA F4/FF4 study. Diabetes Metab Res Rev 2018; 34(5): e3000. doi:10.1002/dmrr.3000 